\title{
PSA Level Ten to Twenty
}

National Cancer Institute

\section{Source}

National Cancer Institute. PSA Level Ten to Twenty. NCI Thesaurus. Code C137687.

A blood concentration of prostate specific antigen between 10 and $20 \mathrm{ng} / \mathrm{mL}$. 